\title{
Struktur Naratif Novel Osakat Anak Asmat Karya Ani Sekarningsih (Perspektif Naratologi Gérard Genette)*
}

\author{
Oleh: \\ Herman Didipu \\ Fakultas Sastra dan Budaya Universitas Negeri Gorontalo \\ Email:herdi.ung@gmail.com HP:085240773101
}

\begin{abstract}
This study aims to describe the narrative structure of Osakat Anak Asmat novel by Ani Sekarningsih. The narrative structure of the novel $O A A$ analyzed based on Gerard Genette's theoretical perspective, which focuses on five narrative structures, namely order, duration, frequency, mood, and voice. The method used is qualitative descriptive. The data analysis is based on Genette's theory of nathology which includes two stages, namely partial analysis and integral analysis. Based on the results of the research, the $O A A$ novel narrative structure structure is as follows. First, the OAA novel formula is structured in the narrative sequence of the achrony. Secondly, there are two narrative duration movements used, ie scene and pause. Third, the narrative frequency used in the novel is a singular representation. Fourth, narrative mood of $O A A$ novel is narrator technique outside story, focalization technique used is zero focalization. Fifth, narrator techniques and focalizations of OAA novels relate to the level of narrative sounds that are heterodiegetik-ekstradiegetik.
\end{abstract}

Abstrak. Penelitian ini bertujuan mendeskripsikan pola struktur naratif novel Osakat Anak Asmat karya Ani Sekarningsih. Struktur naratif novel OAA dianalisis berdasarkan perspektif teori naratologi Gerard Genette yang memfokuskan kajian pada lima struktur naratif, yaitu urutan naratif, durasi naratif, frekuensi naratif, modus naratif, dan suara naratif. Metode yang digunakan adalah metode deskriptif kualitatif. Analisis data didasarkan pada teori naratologi Genette yang meliputi dua tahapan, yaitu analisis parsial dan analisis integral. Berdasarkan hasil penelitian ditemukan pola struktur naratif novel OAA sebagai berikut. Pertama, formula novel OAA disusun dengan pola urutan naratif yang akroni (achrony). Kedua, terdapat dua gerakan durasi naratif yang digunakan, yaitu adegan (scene) dan jeda (pause). Ketiga, frekuensi naratif yang digunakan di dalam novel adalah representasi tunggal (singulative representation). Keempat, modus naratif novel OAA adalah teknik narator di luar cerita, teknik fokalisasi yang digunakan adalah fokalisasi nol. Kelima, teknik narator dan fokalisasi novel OAA berhubungan dengan tingkat suara naratifnya yaitu ekstradiegetik-heterodiegetik.

Kata kunci: novel etnografis, struktur naratif, Gérard Genette

\footnotetext{
* Artikel ini diambil dari sebagian kajian disertasi penulis pada PPs Universitas Negeri Surabaya (2017)
} 


\section{PENDAHULUAN}

Novel Osakat Anak Asmat karya Ani Sekarningsih merupakan salah satu novel etnografis Indonesia. Novel Osakat Anak Asmat (selanjutnya disingkat OAA) dapat disebut sebagai novel etnografis karena di dalamnya banyak mendeskripsikan atau menggambarkan kebudayaan suku Asmat di Papua. Dengan membaca novel ini, pembaca seolah-olah diajak berwisata budaya ke tanah Papua, khususnya ke suku Asmat. Tidak hanya mengenalkan berbagai aturan adat dan budaya suku Asmat, novel itu pun memberikan deskripsi tentang pola pikir dan pola tingkah laku masyarakat setempat sebagai bentuk ekspresi mereka terhadap kehidupan. Singkatnya, novel OAA dapat menjadi "jendela" bagi siapa saja yang ingin mengenali suku Asmat di Papua.

Salah satu kekuatan dari novel ini adalah konstruksi penceritaannya yang mampu merepresentasikan kehidupan masyarakat Asmat dari sudut pandang pengarang atau narator orang luar (outsider). Sebagaimana diketahui bahwa pengarang/narator yaitu Ani Sekarningsih merupakan orang luar Asmat yang hanya melakukan perjalanan ke Asmat Papua. Berbagai pengalaman dan pengamatannya terhadap pola kebudayaan suku Asmat ditransformasikan salah satunya ke dalam novel OAA. Harus diakui bahwa tidaklah mudah mentransformasikan peristiwa-peristiwa realistis yang didasarkan pada pengalaman dan pengamatan visual menjadi peristiwa-peristiwa imajinatif melalui cerita. Dalam hal ini, perlu kepiawaian dan kreativitas khusus dalam merekonstruksi peristiwa nyata ke dalam konstruksi naratif imajinatif.

Aspek naratif (narrative) atau penceritaan menjadi salah satu aspek terpenting dalam sebuah novel. Naratif menjadi kekuatan utama dari novel sehingga mampu menarik perhatian pembacanya. Bahkan, dapat dikatakan bahwa tidaklah mungkin sebuah novel ada tanpa unsur naratif di dalamnya. Dengan hadirnya unsur-unsur naratif, sebuah novel menjadi lebih hidup. Peristiwa-peristiwa (events) nyata dalam kehidupan tidak akan mungkin dapat tersaji menjadi peristiwa-peristiwa imajinatif, jika pengarang tidak kreatif dalam meyusunnya ke dalam bentuk naratif.

Struktur naratif, menurut Genette (1980), terdiri atas lima kategori utama, yaitu (1) urutan naratif (order), (2) durasi naratif (duration), (3) frekuensi naratif (frequency), (4) modus naratif (mood), dan (5) suara naratif (voice). Pertama, urutan naratif (order) mengacu pada hubungan antara urutan kejadian dalam cerita dan pengaturannya dalam cerita. Urutan penyajian cerita dapat secara kronologis atau berurutan maju (prolepsis), dan dapat pula secara non-kronologis atau kilas balik flashback (analepsis). Kedua, durasi naratif (duration) yang menggambarkan 
perbedaan antara waktu yang sebenarnya dari suatu peristiwa (discourse time) dan waktu yang dibutuhkan narator untuk menceritakan peristiwa tersebut (narrative time). Ketiga, frekuensi naratif (frequency) berhubungan dengan keseringan sebuah peristiwa terjadi dalam cerita dan seberapa sering peristiwa tersebut disebutkan dalam cerita. Keempat, modus naratif (mood) yang memfokuskan pada konsep 'jarak' (distance) dan 'perspektif' (perspective) atau fokalisasi (focalization). Kelima, suara naratif (voice) berhubungan dengan siapa yang bercerita, dan dari mana ia bercerita.

Berdasarkan kerangka teori naratologi Genette, penelitian ini bertujuan mendeskripsikan struktur naratif novel Osakat Anak Asmat karya Ani Sekarningsih. Struktur naratif tersebut mencakup urutan naratif (order), durasi naratif (duration), frekuensi naratif (frequency), modus naratif ( $m o o d)$, dan suara naratif (voice).

\section{METODE PENELITIAN}

Metode yang digunakan dalam penelitian ini adalah metode deskriptif kualitatif. Artinya, data penelitian yang berupa data kata, kalimat, dan paragraf, dideskripsikan secara detail sehingga menemukan makna yang utuh dari objek penelitian. Analisis data didasarkan pada teori naratologi Genette seperti yang telah dikembangkan oleh Didipu (2017) yang meliputi dua tahapan, yaitu analisis parsial dan analisis integral. Analisis parsial dilakukan dengan mengidentifikasi masingmasing unsur naratif secara terpisah yang terdiri atas urutan naratif (order), durasi naratif (duration), frekuensi naratif (frequency), modus naratif (mood), dan suara naratif (voice). Setelah analisis parsial pada masing-masing unsur, analisis diarahkan pada keterjalinan unsur-unsur naratif tersebut secara integral. Analisis integral ini dimaksudkan untuk mendapatkan makna keseluruhan dari struktur naratif novel etnografis.

\section{HASIL PENELITIAN DAN PEMBAHASAN \\ Urutan Naratif (Order)}

Novel Osakat Anak Asmat karya Ani Sekarningsih menggunakan pola urutan penceritaan akroni (acrony). Novel OAA menggunakan pola urutan naratif akroni karena terdapat kesejajaran antara waktu cerita dan waktu penceritaannya. Pada tabel berikut didaftarkan urutan peristiwa yang tersusun berdasarkan urutan waktu cerita (dengan angka) dan waktu penceritaan (dengan huruf).

\begin{tabular}{|c|c|c|}
\hline Peristiwa Cerita & $\begin{array}{c}\text { Waktu } \\
\text { Cerita }\end{array}$ & $\begin{array}{c}\text { Waktu } \\
\text { Penceritaan }\end{array}$ \\
\hline $\begin{array}{l}\text { Osakat menjalani keseharian dengan } \\
\text { bermain dan sekolah }\end{array}$ & 1 & $\mathrm{~A}$ \\
\hline
\end{tabular}




\begin{tabular}{|l|c|c|}
\hline $\begin{array}{l}\text { Osakat menyaksikan upacara adat } \\
\text { mbis di rumah adat }\end{array}$ & 2 & $\mathrm{~B}$ \\
\hline $\begin{array}{l}\text { Osakat dan teman-temannya } \\
\text { menyusup ke dalam rumah adat }\end{array}$ & 3 & $\mathrm{C}$ \\
\hline $\begin{array}{l}\text { Mereka ketahuan oleh salah seorang } \\
\text { pemangku adat }\end{array}$ & 4 & $\mathrm{D}$ \\
\hline $\begin{array}{l}\text { Osakat dan Kalektuske pergi } \\
\text { menjenguk adik Wafoco }\end{array}$ & 5 & $\mathrm{E}$ \\
\hline $\begin{array}{l}\text { Ibu Wafoco bersikeras tidak mau } \\
\text { membawa anaknya ke puskesmas } \\
\text { walau sudah dibujuk oleh ibu Osakat } \\
\text { dan suster }\end{array}$ & 6 & $\mathrm{~F}$ \\
\hline $\begin{array}{l}\text { Pak Guru Kindom kesal dan marah } \\
\text { kepada kelas Osakat karena tidak } \\
\text { mau membantunya menyiangi atap } \\
\text { rumahnya }\end{array}$ & 7 & $\mathrm{G}$ \\
\hline $\begin{array}{l}\text { Osakat mengajak teman-temannya } \\
\text { untuk mencari daun-daun rumbia dan } \\
\text { membantu Pak Guru Kindom } \\
\text { memperbaiki atap rumahnya }\end{array}$ & 8 & $\mathrm{H}$ \\
\hline $\begin{array}{l}\text { Kepala sekolah menyampaikan } \\
\text { pengumuman seluruh siswa SMP } \\
\text { diundang melihat ke atas kapal } \\
\text { perang }\end{array}$ & 9 & $\mathrm{H}$ \\
\hline $\begin{array}{l}\text { Osakat dan dua temannya diajak } \\
\text { makan oleh Komandan kapal perang } \\
\text { di ruang makan }\end{array}$ & 10 & $\mathrm{I}$ \\
\hline $\begin{array}{l}\text { Osakat bertemu dengan Gunter, } \\
\text { seorang turis Jerman yang hendak } \\
\text { meneliti kebudayaan di Asmat }\end{array}$ & 11 & $\mathrm{H}$ \\
\hline $\begin{array}{l}\text { Osakat ikut bersama Gunter dalam } \\
\text { kunjungannya ke Gunung Brazza }\end{array}$ & 12 & $\mathrm{O}$ \\
\hline $\begin{array}{l}\text { Bersama Gunter dan tim lainnya, } \\
\text { Osakat melewati rimba rawa Asmat } \\
\text { menuju ke beberapa perkampungan } \\
\text { dan sekolah }\end{array}$ & 13 & \\
\hline $\begin{array}{l}\text { Osakat mengikuti lomba anak } \\
\text { berbakat dan berprestasi sekecamatan }\end{array}$ & 14 & \\
\hline $\begin{array}{l}\text { Osakat menjadi juara umum lomba } \\
\text { anak berbakat dengan ukiran } \\
\text { terbaiknya }\end{array}$ & 15 & \\
\hline
\end{tabular}


Berdasarkan pola formula urutan waktu cerita dan waktu penceritaan yang dikemukakan oleh Genette, maka formula cerita novel OAA adalah sebagai berikut.

\section{A1-B2-C3-D4-E5-F6-G7-H8-I9-J10-K11-L12-M13-N14-O15}

Novel OAA terdiri atas delapan bab. Setiap bab berisi satu peristiwa yang dialami oleh tokoh utama cerita yaitu seorang anak Asmat yang bernama Osakat. Walaupun demikian, peristiwa demi peristiwa dalam novel disusun secara akroni. Cerita diawali dengan rutinitas keseharian Osakat yaitu sekolah dan bermain, menangkap ikan, dan sebagainya. Osakat berharap bisa sebebas teman-temannya yang lain, yang hanya sekolah jika mereka mau ke sekolah. Namun orang tua Osakat tetap mengarahkannya untuk mengutamakan sekolah daripada kegiatan lainnya. Pada bab 2, cerita beralih pada peristiwa upacara adat mbis atau upacara adat tonggak leluhur. Pada kesempatan tersebut Osakat mengajak teman-temannya untuk menyusup ke dalam rumah adat jew untuk mencuri bungkusan ulat sagu. Namun mereka ketahuan oleh seorang pemangku adat dan meminta mereka menyerahkan bungkusan ulat sagu atau akan disidangkan secara hokum ada Asmat.

Peristiwa berlanjut pada bab 3 tentang usaha Osakat untuk membawa adik temannya yang sakit ke puskesmas. Osakat mengajak Kalektuske untuk menjenguk adik Wafoco yang sudah beberapa minggu sakit di rumahnya. Osakat mengusulkan agar adiknya dibawa ke puskesmas, namun ibu Wafoco menolak. Akhirnya Osakat meminta bantuan ibunya dan suster untuk membujuk ibu Wafoco hingga ia bersedia membawa anaknya ke puskesmas. Cerita kemudian beralih ke bab 4 yang berkisah tentang guru Osakat yang bernama Pak Guru Kindom yang kesal dan marah di kelas Osakat karena tidak satu pun di antara mereka yang mau membantunya memperbaiki atap rumahnya yang rusak. Akibatnya, Pak Guru Kindom memutuskan untuk tidak mengajar lagi di kelas Osakat karena dia masih harus memperbaiki atap rumahnya. Osakat berinisiasi dengan mengajak teman-temannya yang lain untuk mencari daun-daun rumbia di hutan. Mereka pun membantu Pak Guru Kindom memperbaiki atap rumahnya. Pak Guru Kindom menjadi senang dan berterima kasih sehingga memutuskan untuk mengajar kembali di kelas Osakat.

Pada bab 5, cerita beralih pada peristiwa datangnya kapal perang ke dermaga. Harapan Osakat untuk bisa naik dan melihat-lihat isi kapal akhirnya terwujud setelah Kepala Sekolah menyampaikan pengumuman bahwa semua siswa di sekolahnya diundang untuk melihat dan bertanya langsung ke atas kapal perang. Hal itu tidak disia-siakan oleh Osakat dengan banyak bertanya kepada para ABK dan petugas kapal tentang sejarah, fungsi, dan berbagai hal tentang kapal perang 
tersebut. Ternyata rasa ingin tahu Osakat dan beberapa temannya menarik perhatian Komandan kapal tersebut hingga mereka diajak makan oleh Komandan dan para petinggi di kapal tersebut. Peristiwa selanjutnya beralih ke bab 6 tentang pertemuan Osakat dengan Gunter, seorang turis kebangsaan Jerman yang hendak meneliti kebudayaan Asmat. Gunter mengajak Osakat untuk mendampinginya melakukan perjalanan untuk mengunjungi kelompok-kelompok suku yang ada di Gunung Brazza. Osakat pun mengonsultasikan rencana tersebut dengan ayahnya. Tanpa ragu dan dengan memberikan pesan-pesan tentang berbagai aturan dan hokum adat Asmat, ayahnya pun mengizinkannya mendampingi Gunter.

Papa bab 7 peristiwa berlanjut pada perjalanan Osakat, Gunter, dan rombongan. Mereka menelusuri lembah dan rimba rawa Asmat, menuju ke beberapa perkampungan dan sekolah di Asmat. Dalam perjalanan tersebut mereka banyak menyaksikan keunikan tanaman yang hidup di bumi Asmat. Tidak sedikit pula mereka melewati beberapa perkampungan dengan ciri budaya dan dialek sendiri. Bab terakhir berkisah tentang keinginan Osakat mengikuti lomba anak berbakat dan berprestasi tingkat kecamatan yang digelar dalam rangka hari kemerdekaan 17 Agustus. Untuk mempersiapkan dirinya, Osakat terus mengasah kreativitasnya mengukir patung hingga harus menyepi ke tengah hutan. Hasil ukirannya pun selesai dan siap dinilai oleh tim juri. Tak disangka akhirnya Osakat menjadi juara umum lomba pengukir terbaik. Sebagai bentuk penghargaan, seorang pengusaha sukses memberikannya beasiswa hingga perguruan tinggi.

\section{Durasi Naratif (Duration)}

Terdapat dua gerakan naratif yang digunakan dalam novel Osakat Anak Asmat, yaitu adegan (scene) dan jeda (pause). Dari kedua jenis gerakan naratif ini, adegan lebih dominan daripada jeda. Adegan lebih dominan di dalam cerita karena mendukung hadirnya urutan naratif akroni yang menyejajarkan waktu cerita dan waktu naratifnya. Sementara jeda hanya ditemukan pada beberapa bagian cerita. Itupun tidak terlalu panjang karena hanya menyisip pada inti cerita. Beberapa jeda yang ditemukan di dalam novel hanya bersifat kilasan singkat yang berfungsi sekadar mengantarkan pengetahuan dan imajinasi pembaca pada fokus cerita selanjutnya.

Jeda (pause) terjadi jika naratif terputus karena disisipi oleh cerita lain yang sifatnya tidak dominan. Dalam jeda, waktu naratif tetap menduduki posisi dominan, sedangkan waktu cerita hanya menjadi bagian kecil naratif. Berikut beberapa contoh jeda di dalam novel Osakat Anak Asmat. 
Ketiga sahabatnya itu, Bicem, Wafoco, dan Kalaktuske sering turut dengan ayahnya menebang jauh ke hutan. Berminggu-minggu tidak sekolah. Ia pernah dibuat kagum oleh ketiga temannya yang menceritakan wajah Pak Guru Mathias Simpu, yang menjemput ketiga sahabat tersebut dengan suara memelas, agar sekolah. Ayah mereka menyambutnya dengan busur panah yang terpentang.

"Anak itu milik kami, Guru. Banyak yang mereka harus kerjakan. Disini mereka mendapat upah sedangkan di sekolah tidak."

"Bukan begitu Bapak. Zaman berubah terus. Kita dituntut harus jadi lebih cerdas. Andai membaca, menulis, dan berhitung," kata Pak Guru Mathias.

"Apakah guru menjamin anak saya dapat menjadi camat di kemudian hari?" tantang ayah mereka dengan suara bersamaan.

(Sekarningsih, 2002:3)

Data novel di atas dikatakan jeda karena hanya diceritakan sekilas oleh narator. Ketika itu tokoh Osakat kesal karena ibunya selalu memaksanya untuk ke sekolah. Ia berharap ibunya seperti orang tua ketiga temannya tersebut, yang justru lebih suka mengajak anak mereka ke hutan. Bahkan, ketika ada guru mereka yang menjemput mereka untuk ke sekolah, ayah mereka justru menantang guru tersebut. Kisah itu diceritakan secara sepintas yang hanya untuk memperkuat alasan pikiran Osakat sehingga pembaca menjadi lebih mengetahui apa yang dipikirkannya.

Contoh lain dari jeda di dalam novel dapat dilihat pada data berikut ini.

Tiba-tiba Osakat teringat bahwa sudah dua minggu adik Wafoco, Banew, tergolek sakit, sejak keluarga itu pulang dari penebangan di hutan. Setahunya, sampai dengan hari kemarin belum seorang pun membawanya ke Puskesmas. Lima hari lalu, Osakat melihat Pak Tua Jokor, seorang cenayang terkemuka, menyulut tubuh kecil itu dengan sepotong punting kayu bara yang menyala pada dada kirinya hingga menimbulkan jeritan panjang yang mengenaskan.

"Ah, bagaimana keadaan anak perempuan itu." Ia berbicara sendiri.

(Sekarningsih, 2002:15)

Data di atas merupakan jeda singkat ketika Osakat sedang memahat ukiran patung barunya. Tiba-tiba ia teringat adik temannya yang sedang sakit. Sekilas narator menyisipkan cerita singkat dalam ingat Osakat yang nantinya menjadi bagian pokok cerita pada bab 3. Ingatan Osakat pada adik temannya, Wafoco, menjadi jeda singkat yang mengantarkan cerita pada usaha Osakat membujuk ibu Wafoco dan 
membawa adiknya Banew berobat ke Puskesmas. Usaha itu akhirnya tidak sia-sia karena pada akhirnya Ibu Wafoco mau membawa anaknya berobat ke Puskesmas.

\section{Frekuensi Naratif (Frequency)}

Frekuensi naratif yang digunakan di dalam novel Osakat Anak Asmat adalah representasi tunggal (singulative representation). Artinya, setiap peristiwa yang terjadi sekali di dalam novel hanya dikisahkan atau diceritakan sekali pula. Tidak ditemukan pengulangan-pengulangan kejadian atau peristiwa yang sama di dalam novel tersebut. Setiap peristiwa yang dialami oleh tokoh, baik tokoh utama maupun tokoh lainnya, hanya diceritakan sekali selama penceritaan novel. Beberapa contoh peristiwa penting yang dialami oleh tokoh utama dan beberapa tokoh lain di dalam novel seperti dikutipkan berikut ini.

"Baik, semua tidak bersedia menjelaskan," Enakap menatap tajam. "Bicem, segera kamu kembalikan benda itu ke tempatnya. Cepat lakukan atau sekarang juga saya menyidangkan kamu di hadapan seluruh pemuka adat." Sekonyong-konyong dari balik asap terdengar perintah Pak Tua Owitipits penuh wibawa.

"Anak-anak itu tentu sudah mengambil bungkusan ulat sagu, Enakap," katanya kepada ayah Osakat.

Ayah Osakat menatap berang keempat anak-anak tersebut.

Semua mendapat jatah tempelengnya. Ia harus mendidik mereka agar tidak mengulang perbuatan yang tidak terpuji itu.

(Sekarningsih, 2002:11)

Data di atas merupakan contoh peristiwa penting yang dialami oleh Osakat dan teman-temannya yang kedapatan mencuri bungkusan ulat sagu di dalam rumah adat. Dalam prosesi peradatan suku Asmat, bungkusan ulat sagu merupakan salah satu makanan khas yang disajikan pada saat prosesi upacara sakral mbis atau upacara tonggak leluhur. Setelah prosesi selesai, setiap kepala keluarga mendapatkan jatah bungkusan ulat sagu yang selanjutnya dibagikan kepada seluruh anggota keluarganya. Karena merasa hanya sering mendapat jatah sedikit, Osakat dan teman-temannya mencuri bungkusan ulat sagu yang tersimpan di dalam rumah adat. Pada akhirnya ketahuan oleh pemangku adat. Peristiwa ini hanya diceritakan sekali di dalam novel, tepatnya pada halaman 11 .

Contoh kedua di bawah ini adalah peristiwa penting yang dirasakan oleh Osakat ketika dinyatakan sebagai pemenang lomba mengukir dan anak berbakat dalam rangka 17 Agustus. Osakat merasa sangat senang karena mampu menunjukkan kemampuannya mengukir patung dengan jelimet dan mampu menjadi yang terbaik 
di antara sekian banyak pengrajin ulung di Asmat. Berkat kemampuannya itu, seorang pengusaha sukses berjanji akan memberikan beasiswa pendidikannya. Peristiwa ini hanya diceritakan sekali pada menjelang akhir novel, yaitu pada halaman 64-65.

Ketua panitia masih tegak di depan corong mikrofon. Ia memerluka beberapa waktu diam dan membalik-balik lembaran kertas. Pengeras suara itu lalu mengeluarkan bunyi. Menggelegar memecah jeda kesunyian.

"Adapun juara umum diraih oleh ...." Ketua panitian mengelilingkan pandangannya kepada para tamu. "Osakat. Murid SMP Negeri Agats!"

Osakat tersentak, gugup. Ia tidak percaya namanya dipanggil. Ia menyadari seluruh penonton yang memenuhi lapangan kecamatan tertuju kepadanya. Tidak urung dalam hati menyelinap perasaan ragu dan malu.

(Sekarningsih, 2002:61)

Dominasi durasi frekuensi tunggal dalam novel OAA mendukung hadirnya pola urutan naratif yang sifatnya akroni. Penceritaan tunggal terhadap satu peristiwa menyebabkan urutan naratif berjalan sejajar antara waktu cerita (story time) dan waktu penceritaannya (narrative time). Selain itu, dominasi frekuensi tunggal digunakan oleh pengarang untuk bisa lebih banyak mendeskripsikan hal-hal yang dirasa penting diceritakan, yaitu deskripsi kebudayaan. Dengan kalimat lain, frekuensi tunggal memungkinkan pengarang untuk lebih banyak mendeskripsikan aspek kebudayaan masyarakat suku Asmat, terutama yang berkaitan dengan berbagai pola pikir dan perilaku masyarakat setempat dalam berinteraksi sosial.

\section{Modus Naratif (Mood)}

Dalam menyampaikan ceritanya, pengarang menggunakan teknik narator yang bukan merupakan tokoh dalam cerita, analisis internal peristiwa, pengarang mahatahu atau analitis dalam mengisahkan cerita. Narator berada di luar cerita, dan hanya mengisahkan tokoh utama Osakat dan beberapa tokoh lainnya. Walaupun berada di luar cerita, narator mampu mengisahkan setiap peristiwa yang dialami oleh tokoh utama dan beberapa tokoh lain secara detail dan mendalam. Narator bersifat mahatahu dan analitis terhadap bentuk fisik, pikiran dan perasaan beberapa tokoh di dalam novel. Berikut contoh data dari dalam novel Osakat.

“Osakat, bungkusan apa itu?" sekarang Enakap berbalik, bertanya langsung menghadapi putranya. Sebagai lelaki sejati Osakat tidak menjawab. Atau ia memperoleh pengakuan sebagai sebagai seorang penghianat, dan kemudian menjadi bahan olok-olokan seluruh kampung dan dijauhi teman-teman sebaya. Demikian pula dengan kedua temannya yang lain, ketika ayahnya meminta penjelasan, tidak seorang pun membuka mulut.

(Sekarningsih, 2002:11) 
Data novel di atas memperlihatkan teknik penceritaan yang naratornya berada di luar cerita. Narator hanya mengisahkan atau menceritakan tokoh-tokoh di dalam cerita dengan cara melaporkan semua hal yang dialami tokoh-tokoh. Walaupun demikian, narator mampu menceritakan sedetail mungkin apa yang dialami dan dirasakan oleh tokoh-tokoh di dalam cerita. Pada contoh data di atas, narator bahkan mampu meramalkan sesuatu yang akan terjadi jika tokoh Osakat dan dua temannya mengakui perbuatan mereka. Ini membuktikan bahwa walaupun tidak secara langsung menjadi tokoh utama di dalam cerita, pengarang mampu mendeskripsikan secara mendalam berbagai hal yang berhubungan isi cerita.

Teknik fokalisasi yang digunakan adalah fokalisasi nol, yaitu narator tahu lebih tentang apa yang diketahui oleh satu atau beberapa tokoh. Narator mahatahu berbagai hal tentang tokoh di dalam cerita. Bentuk fisik, apa yang dirasakan, apa yang dipikirkan, bahkan apa yang akan dialami oleh tokoh bisa diprediksi. Tidak hanya pada satu tokoh utama, namun sampai beberapa tokoh. Berikut contoh teknik fokalisasi dalam novel Osakat.

Usia Osakat sekarang empat belas tahun. Badannya tegap, kukuh, serta padat berisi. Rambutnya keriting lada, berwarna hitam pekat. Baru enam bulan ia duduk di kelas satu SMP. Sementara Bicem dan Wafoco yang berusia 16 dan bertumbuh tinggi dari Osakat masih duduk di kelas 5. Owey dan Kalektuske sebaya dengan Osakat, masih duduk dikelas 4, murid ibunya.

(Sekarningsih, 2002:3)

Ceritanya, Pak Guru Kindom kesal. Rumahnya sudah banyak bocor. Untuk menyiangi atap daun rumbia rumahnya ia harus mencari bahan-bahannya sendiri di hutan. Akan tetapi, pekerjaan mengajarnya tidak sedikit. Ia harus membuat persiapan, membuat soal-soal ulangan, dan memeriksa hasil-hasil ulangannya sekaligus. Sementara murid-murid kelasa tiga harus dipersiapkan lebih ketat menghadapi ujian akhir yang sudah mendesak. Padahal ia juga masih harus tambahan penghasilan karena gaji yang diterimanya selalu terlambat, tidak cukup. Sedangkan biaya di daerah terpencil seperti Asmat, mencekik leher.

(Sekarningsih, 2002:22)

Pada data pertama, narator mendeskripsikan bentuk fisik tokoh Osakat dan tokohtokoh lainnya. Secara detail narator menggambarkan bentuk tubuh, tinggi badan, hingga usia mereka. Penggambaran seperti ini lebih mengkonkretkan kehadiran tokoh-tokoh cerita sehingga pembaca secara imajinatif dapat membayangkan keadaan fisik tokoh-tokoh tersebut. Pada data kedua, narator menggambarkan perasaan kesal tokoh Pak Guru Kindom yang merasa kesal karena harus memperbaiki rumahnya di tengah-tengah himpitan tugas mengajarnya. Dua contoh 
data di atas menjelaskan teknik fokalisasi yang secara akurat mampu mendeskripsikan berbagai keadaan tokoh-tokoh cerita hingga pada berbagai deskripsi kebudayaan suku Asmat. Dengan demikian, walaupun narator tidak secara langsung hadir dalam cerita, namun ia mampu mendeskripsikan secara detail berbagai seluk beluk kehidupan masyarakat Asmat.

\section{Suara Naratif (Voice)}

Waktu penceritaan novel Osakat Anak Asmat adalah simultaneous atau penceritaan masa kini, yaitu teknik penceritaan yang mengambil latar waktu penceritaan pada satu masa yang terjadi di dalam novel. Sementara novel Osakat Anak Asmat menggunakan teknik narator heterodiegetik, yaitu teknik penceritaan yang narator atau penceritanya berada di luar cerita. Dengan demikian, novel ini berada pada tingkat naratif ekstradiegetik-heterodiegetik, yaitu tingkat naratif pertama yang naratornya tidak hadir dalam ceritanya.

Waktu penceritaan yang simultaneous sesuai dengan teknik waktu naratif yang digunakan dalam novel ini yaitu akroni. Untuk jelasnya, berikut dua data peristiwa yang menggambarkan waktu penceritaan simultaneous atau waktu penceritaan masa kini dalam novel Osakat Anak Asmat.

Pertama kali Osakat masuk dalam lingkungan rumah adat, tepat saat diadakan awal pesta upacara mbis. Yakni upacara membuat tonggak leluhur berupa patung bersusun setinggi $12 \mathrm{~m}$ terbuat dari jenis pohon bakau yang mempunyai akar papan yang lebar. Guna memperingati meninggalnya salah seorang kakek dari pihak Enakap, ayah Osakat.

(Sekarningsih, 2002:5)

Osakat tidak sepenuhnya memahami dialeg bahasa mereka. Namun, hampir setiap irama lagu, Osakat dapat merasakan irama napas alam itu sendiri. Penaklukan terhadap kekalahan dan kemenangan selama berates-ratus tahun yang mewarnai hidup orang-orang yang akrab dengan hutan rawa. Ada semacam nada kerinduan pada keheningan semesta yang entah di mana. Kecuali mengatasnamakan tiap peristiwa pada dunia arwah para leluhur. Gunter menyerahkan tembakau Lampion dan beberapa bungkus rokok kepada salah seorang di antara mereka.

(Sekarningsih, 2002:48)

Dua data di atas merupakan contoh peristiwa yang dialami oleh tokoh utama yaitu Osakat. Dua contoh peristiwa tersebut terjadi secara kronologis dan berurut sesuai alur cerita. Peristiwa pertama terjadi ketika Osakat diajak oleh ayahnya pergi ke rumah adat untuk menyaksikan upacara sacral yaitu upacara adat mbis. Peristiwa 
ini diceritakan oleh narator pada bagian-bagian awal cerita. Peristiwa kedua merupakan contoh peristiwa yang dijalani oleh Osakat ketika ia mendampingi Gunter, seorang turis asal Jerman, yang sedang melakukan penelitian kebudayaan di Asmat. Semua peristiwa diceritakan secara kronologis atau akroni dengan waktu penceritaan yang sama dengan peristiwa yang dialami oleh tokoh.

Novel Osakat Anak Asmat Ani Sekarningsih menggunakan teknik narator heterodiegetik dalam menyampaikan ceritanya. Teknik narator heterodiegetik digunakan dengan cara narator bercerita tentang tokoh-tokoh di dalam cerita sedangkan narator sendiri berada di luar cerita. Narator hanya menjadi pelapor dari peristiwa yang dialami oleh tokoh-tokoh di dalam cerita. Berikut contoh data dalam novel.

Ia tertarik akan Asmat sejak kunjungannya semasa masih mahasiswa di Aachen Universiteit. Tatkala ia berkunjung ke Musium Metropolitan di New York dan mendengar penjelajahan Michael Rockefeller menyusuri sungai Unir melalui pegunungan Jayawijaya hingga tewas digulung ombak lautan Arafura di Pantai Kasuari. Ia mengagumi koleksi deretan patung mbis yang mencapai ketinggian 1 meter. Megah berbaris di museum yang bergengsi itu. Lain dengan yang ada di museum Tropen di Amsterdam atau di museum Volkerkunde di Roterdam, yang menayangkan artefak alat-alat rumah tangga, berupa terompet berukir, piring sagu, dayung, kepala perahu, tifa, batu bintang untuk menokok kepala musuh dan benda-benda kecil lainnya.

(Sekarningsih, 2002:41)

Yah, mereka sesungguhnya orang-orang kaya. Namun kemudian Osakat sadar. Ada yang berubah di sekelilingnya. Nilai kekayaan dan kesejahteraan, sekarang ini ditentukan dengan nilai uang. Pola makan berubah. Mereka sekarang memilih membeli beras yang mudah mengolahnya. Lain halnya dengan proses sagu, perlu waktu lima belas tahun untuk dapat memanen sari patinya. Sementara kebiasaan menebang pohon sagu tidak hanya pohon yang bernas dirubuhkan, tetapi juga dibarengi dengan pohon sagu muda yang ditebang dan mubazir. Pikiran mengukur laba rugi suatu proses kehidupan itu sudah saling berulang menamparnampar kepalanya yang kecil. Betapa sulitnya uang ditempatnya.

(Sekarningsih, 2002:50-51)

Dalam dua data novel di atas, narator memosisikan dirinya sebagai pengamat yang melaporkan apa yang diamatinya tentang tokoh-tokoh di dalam cerita. Data pertama tampak narator bercerita tentang tokoh Gunter yang kagum akan kekayaan alam dan budaya suku Asmat. Demikian pula pada data kedua, narator mengamati secara 
detail dan menyampaikan apa yang dirasakan dan dipikirkan oleh tokoh Osakat kepada pembaca. Teknik narator heterodiegetik ini sangat relevan dengan teknik fokalisasi yang digunakan oleh pengarang, yaitu fokalisasi nol.

\section{KESIMPULAN}

Berdasarkan hasil analisis dan pembahasan disimpulkan struktur naratif novel Osakat Anak Asmat karya Ani Sekarningsih sebagai berikut. Pertama, formula novel OAA disusun dengan pola urutan naratif yang akroni (achrony), yaitu terdapat kesejajaran antara waktu cerita dan waktu penceritaannya. Kedua, terdapat dua gerakan durasi naratif yang digunakan, yaitu adegan (scene) dan jeda (pause). Adegan lebih dominan di dalam cerita karena mendukung hadirnya urutan naratif akroni yang menyejajarkan waktu cerita dan waktu naratifnya. Sementara jeda hanya ditemukan pada beberapa bagian cerita. Ketiga, frekuensi naratif yang digunakan di dalam novel adalah representasi tunggal (singulative representation). Artinya, setiap peristiwa yang terjadi sekali di dalam novel hanya dikisahkan atau diceritakan sekali pula. Frekuensi naratif tunggal mendukung hadirnya urutan naratif yang akroni. Selain itu, hal tersebut memungkinkan pengarang untuk mendeskripsikan kebudayaan suku Asmat lebih banyak lagi. Keempat, modus naratif novel OAA adalah teknik narator di luar cerita, teknik fokalisasi yang digunakan adalah fokalisasi nol, yaitu narator tahu lebih tentang apa yang diketahui oleh satu atau beberapa tokoh. Teknik narator dan fokalisasi novel OAA berhubungan dengan tingkat suara naratifnya yaitu ekstradiegetik-heterodiegetik. Tingkat naratif ekstradiegetik-heterodiegetik, yaitu tingkat naratif pertama yang naratornya tidak hadir dalam ceritanya. Adapun waktu penceritaan novel OAA adalah simultaneous atau penceritaan masa kini, yaitu teknik penceritaan yang mengambil latar waktu penceritaan pada satu masa yang terjadi di dalam novel.

\section{DAFTAR PUSTAKA}

Didipu, Herman. (2017). Struktur dan Simbol Narasi Budaya dalam Novel Etnografis: Kajian Interpretatif Simbolik. Disertasi tidak diterbitkan. Surabaya, PPs UNESA.

Genette, Gérard. (1980). Narrative Discourse: An Essay in Method. Translated by Jane E. Lewin. New York: Cornell University Press.

Sekarningsih, Ani. (2002). Oskata Anak Asmat. Jakarta: Dewata Publishing. 